Tarbawy : Jurnal Pendidikan Islam

ISSN : 2407-4462 (Cetak), 2614-5812 (Elektronik)

Vol. 8, No. 2, 2021, Hal. 46-60

DOI: https://doi.org/10.32923/tarbawy.v8i2.1796

\title{
Implikasi Pendidikan Agama Dalam Keluarga Living Qur'an Surat Luqman Ayat 13-19
}

\author{
Suriadi $^{1}$, Dedi $^{2}$ \\ ${ }^{1}$ IAIN Sultan Muhammad Syafudin Sambas \\ ${ }^{2}$ MAN Insan Cendikia Sambas
}

\section{Info Artikel :}

Diterima 2 September 2021

Direvisi 15 September, 2021

Dipublikasikan 21 oktober 2021

\section{Kata Kunci: \\ Implikasi \\ Keluarga \\ Surah Lukman}

\section{Keywords: \\ Implications, \\ Family,}

Surah Luqman

\begin{abstract}
ABSTRAK
Artikel ini mengkaji tentang implikasi pendidikan agama dalam keluarga berdasarkan surat Luqman Ayat 13-19. Dari penelitian tersebut dapat diketahui bahwa pada surat luqman ayat 13-19 sesungguhnya dapat dijadikan sebagai acuan bagi orang tua terhadap materi pokok pendidikan agama Islam yang harus disampaikan kepada anak-anaknya. Karena di dalam surat luqman ayat 13-19 telah mencakup tiga aspek pendidikan agama Islam; yaitu 1) pendidikan aqidah yang mencakup tentang a) keimanan (pengesaan) kepada Allah swt, keyakinan tauhid yang sebersih-bersihnya yaitu larangan mempersekutukan Allah. b)Kesadaran akan kemakhlukan kita yang wajib mensyukuri segala karunia Tuhan, dan c) Kesadaran bahwa segala gerak-gerik yang nampak maupun yang tersembunyi tidak lepas dari pengetahuan dan pengawasan Tuhan. 2) Pendidikan Ibadah. Pada aspek ibadah ini, yang paling pokok adalah mengenai: a) perintah shalat, berupa perintah melaksanakan shalat fardu lima kali sehari, dan shalat nawafil lainnya. b) perintah amar ma'ruf. Dalam pelaksanaannya pada anak-anak adalah anak-anak dibiasakan dalam berhubungan dengan manusia dengan mengerjakan amal-amal shaleh dan menyuruh orang lain melakukan kebaikan. c) perintah mencegah yang munkar. Bagi anak prakteknya adalah ditanamkan kepada anak akan rasa benci dan tidak melakukan segala perbuatan yang munkar yaitu segala perbuatan yang bertentangan dengan agama. d) perintah melaksanakan kesabaran dalam menghadapi segala ujian, cobaan yang menimpanya. 3) Pendidikan Akhlak. Pada aspek pendidikan akhlak yang perlu ditanamkan kepada anak, meliputi: a) bertutur kata yang lemah lembut dengan siapapun, terutama dengan orang tua. b) larangan berlaku sombong atau takabur dengan siapapun juga baik dalam berbicara (tidak memalingkan muka) maupun berjalan. c) berlaku sederhana dalam hidup dan kehidupannya.
\end{abstract}

\begin{abstract}
This article examines the implications of the subject matter of religious education in the family based on the letter Luqman Verses 13-19. From this research it can be seen that in the letter luqman verses 13-19 can actually be used as a reference for parents of the basic material of Islamic education that must be delivered to their children. Because in the letter luqman verses 13-19 have covered three aspects of Islamic religious education; namely 1) aqidah education which includes about a) faith (rustic) to God Almighty, belief in monotheism as thoroughly as possible, namely the prohibition of associating partners with God. b) Awareness of our supremacy which is obliged to be grateful for all the gifts of God, and c) Awareness that all visible and hidden movements cannot be separated from God's knowledge and supervision. 2) Worship Education. In this aspect of worship, the most important thing is about: a) prayer orders, in the form of orders to perform fardu prayers five times a day, and other nawafil prayers. b) command amar ma'ruf. In its implementation in children are children accustomed in dealing with humans by doing pious deeds and asking others to do good. c) order to prevent evil. For children the practice is to inculcate the child with hatred and not do any evil deeds, ie all actions that are contrary to religion. d) orders to exercise patience in the face of all tests, trials that befall him. 3) Moral Education. In the aspect of moral education that needs to be instilled in children, includes: a) speaking soft words with anyone, especially with parents. b) prohibition applies arrogant or arrogant with anyone either in talking (not looking away) or walking. c) apply simply in life and life.
\end{abstract}

This is an open access article distributed under the Creative Commons Attribution License, which permits unrestricted use, distribution, and reproduction in any medium, provided the original work is properly cited. 02019 by a 


\section{Pendahuluan}

\section{Pendahuluan}

Islam mengajarkan agar manusia dapat memimpin dirinya sendiri, memimpin keluarganya dan memikul berbagai tanggung jawab yang menjadi tugasnya di masyarakat, sebagaimana Nabi saw. bersabda:" setiap kamu adalah pemimpin atas (tugas) apa yang dipimpinnya". ${ }^{1}$ Oleh karena itu, setiap Muslim harus memiliki kemampuan untuk menjadi pemimpin. Dia harus memiliki pengetahuan atas apa yang dipimpinnya sehingga tugas itu akan berjalan dengan baik dan membuat apa yang dipimpinnya itu menjadi baik pula. Sebagai kepala rumah tangga, seorang ayah harus menguasai ilmu untuk memimpin keluarganya dengan baik; sebagai wakil suami, seorang ibu harus mampu memimpin anak-anaknya dan mengatur rumah tangganya dengan baik. Anak-anak pun harus dididik agar dapat memimpin dirinya sendiri untuk menjadi manusia-manusia yang baik.

Islam menganjurkan agar kehidupan keluarga menjadi bahan pemikiran setiap insan dan hendaknya darinya dapat ditarik pelajaran berharga. Menurut pandangan Al-Qur'an, kehidupan kekeluargaan, disamping menjadi salah satu tanda dari sekian banyak tanda-tanda kebesaran Ilahi, juga merupakan nikmat yang harus dapat dimanfaatkan sekaligus disyukuri. ${ }^{2}$

Pemikiran sosial dalam Islam ada kesesuaian dengan pemikiran sosial modern yang mengatakan bahwa keluarga itu adalah unit terkecil dan institusi pertama masyarakat dimana berbagai hubungan yang terdapat di dalamnya, sebahagian besarnya bersifat hubungan-hubungan langsung. Disitulah berkembang individu dan disitulah terbentuknya tahapan awal proses pemasyarakatan (socialization), dan melalui interaksi dengannya ia memperoleh pengetahuan, ketrampilan, minat, nilai, emosi dan sikapnya dalam hidup dan dengan itu ia memperoleh ketentraman dan ketenangan. Menurut Al-Zaghlami seperti dikutip oleh Hasan Langgulung mengungkapkan bahwa Islam memandang keluarga sebagai lingkungan atau millieu pertama bagi individu dimana ia berinteraksi. Dari interaksi dengan lingkungan pertama itu individu memperoleh unsur-unsur dan ciri-ciri dasar kepribadiannya, memperoleh akhlak, nilai-nilai, kebiasaankebiasaan dan emosinya dan dengan itu ia merobah banyak kemungkinan-kemungkinan, kesanggupankesanggupan dan kesediaannya menjadi kenyataan yang hidup dan tindaklaku yang tampak. ${ }^{3}$

Menyangkut konsep pendidikan keluarga banyak mengadopsi sistem pendidikan keluarga ala barat, yang menekankan pada aspek materialisme, seperti anak harus dididik untuk menguasai teknologi tanpa didasari pengetahuan dan pengamalan agama yang mendalam. Padahal dalam Islam fitrah manusia baik, keluaga dalam hal ini ayah dan ibu dalam mendidik anak-anaknya seyogyanya mengetahui dan memahami pendidikan agama.

Untuk menetapkan fitrah seperti itu diperlukan upaya pendidikan yang sifatnya manusiawi melalui pendidikan kemanusiaan, yaitu pendidikan yang memanusiakan manusia. Sejak lahir manusia telah membawa fitrah (potensi), kecenderungan menjadi orang baik atau jahat, menjadi baik atau buruk. Hal itu tergantung interaksi manusia terhadap lingkungan sekitarnya. Oleh karena itu, dalam upaya melestarikan

\footnotetext{
Suriadi, 'Pendidikan Agama Dalam Keluarga', $15.2 \quad$ (2019), 89-105 <https://doi.org/10.32939/tarbawi.v15i1.326>.

2 M. Quraish Shihab and Ihsan Ali-Fauzi, Membumikan' Al-Qur'an: fungsi dan peran wabyu dalam kehidupan masyarakat (Bandung: Mizan, 2002).

${ }^{3}$ Hasan Langgulung, Manusia dan pendidikan: suatu analisa psikologi, filsafat dan pendidikan (Jakarta: Al Husna Zikra, 1995).
} 
dan mengembangkan fitrahnya yang lebih baik, maka diperlukan proses pendidikan dengan tujuan agar fitrah tersebut tetap pada ketentuan Allah. ${ }^{4}$

Pengetahuan ini sangat penting dimiliki oleh keluarga karena untuk membentuk anak-anak yang shalih, berkualitas, dan berakhlak karimah. Sementara dalam kenyataan dijumpai banyak orang tua yang belum mengerti dan memahami ajaran pokok agamanya. Sehingga banyak dijumpai tidak sedikit anak-anak yang melakukan perbuatan yang melanggar nilai-nilai agama. Kita melihat kondisi sekarang dengan terjadinya berbagai aksi kekerasan, kriminal, anak-anak tidak menutup kemungkinan karena kurangnya pendidikan agama dalam keluarga. Orang tua dan masyarakat mengetahui bahwa kehidupan ini semakin hari semakin komplek, mereka mengetahui bahwa apa yang berlaku pada zaman mereka ada yang tidak berlaku lagi bagi anak-anak mereka dan bahwa suasa yang dihadapi anak-anak mereka lebih komplek. Karena itulah nilai-nilai yang dapat ditanamkan di lingkungan keluarga menyangkut keyakinan hidup, akhlak, persiapan anak-anak hidup di masyarakat, serta tuntutan hidup atau kehidupan beragama mempunyai pengaruh besar bagi anggota keluarga. Islam sebagai suatu ajaran memberikan prioritas tersendiri terhadap pendidikan. Hal ini dapat dicermati melalui petunjuk informasi dalam al-Qur'an. AlQur'an sebagai sumber hukum pertama dalam Islam diturunkan kepada umat manusia untuk memberi petunjuk kearah jalan hidup yang lurus dalam arti memberikan bimbingan dan petunjuk ke arah jalan yang diridlai Allah swt. Menurut Islam, penanggung jawab pendidikan yang sesungguhnya adalah orang tua; ayah dan ibu. Abdullah Nashih 'Ulwan mengatakan bahwa mereka memiliki kewajiban untuk bertanggung jawab terhadap anak-anaknya dalam bidang kehidupan biologis, intelektual, psikis, sosial, dan seks. Kesehatan dan kesadaran diberbagai bidang tersebut adalah tanggung jawab orang tua. ${ }^{5}$

Ahmad Tafsir mengemukakan bahwa banyak orang tua mempercayakan seratus persen pendidikan agama bagi anaknya ke sekolah, karena di sekolah ada pendidikan agama dan ada guru agama. Sebagian orang tua menambah pendidikan agama bagi anaknya dengan cara menitipkan anaknya ke 'pesantren sungguhan', pesantren kilat, atau mendatangkan guru agama ke rumah. Maksudnya diharapkan bahwa anak-anak mereka akan menjadi orang yang beriman dan bertakwa. Tindakan orang tua tersebut dapat dibenarkan, namun belum mencukupi. Karena pada dasarnya pendidikan agama dalam keluarga itu dilakukan oleh orang tua. Orang tua adalah pendidik utama dan pertama dalam keluarga. Disebut pendidik utama karena besar sekali pengaruhnya. Disebut pendidik pertama karena merekalah yang pertama mendidik anaknya. Oleh karena itu menyerahkan seratus persen pendidikan agama bagi anak-anak kita ke sekolah, pesantren, dan atau kepada guru agama yang diundang ke rumah merupakan tindakan yang berbahaya. ${ }^{6}$

Penanaman pendidikan agama dalam keluarga saat ini memiliki dua kendala; pertama banyak orang tua yang belum menyadari hal ini. kedua banyak orang tua yang belum mengetahui caranya termasuk dalam hal ini juga adalah materi apa saja yang harus di ajarkan pada anak-anaknya. Seperti semua orang tahu bahwa pendidikan dalam keluarga adalah informal, tidak ada kurikulum yang dijadikan pegangan. Orang tua tidak banyak mengetahui masalah pendidikan dan pengajarannya. Oleh karena itu untuk mencari dan merumuskan bahan atau materi yang harus dididikkan kepada anak usia 6-12 tahun oleh orang tua di rumah amatlah sulit Tentu saja, orang tua perlu dibekali dengan berbagai bahan dan materi yang tepat bagi pendidikan agama anaknya serta cara pelaksanaannya. ${ }^{7}$

\footnotetext{
4 Suriadi, 'Hakikat Fitrah Manusia Dalam Islam', 2020, 85-100 <https://doi.org/10.35905/alishlah.v18i1.1278>.

${ }^{5}$ Abdullah Nashih Ulwan, Tarbiyat Al-Aulad Fi Al-Islam (Beirut: Dar al-Salam, 1971).

${ }^{6}$ Ahmad Tafsir, Pendidikan Agama Dalam Keluarga (Bandung, Indonesia: PT Remaja Rosdakarya, 2000).

7 Ahmad Tafsir.
} 


\section{Keluarga}

Sebagai suatu lembaga pendidikan, tentu saja keluarga menjalankan proses kependidikan dan manajemennya untuk mencapai tujuan yang dicita-citakan. Dalam pendidikan Islam menyatakan bahwa Allah sebagai Rabb (pendidik) alam, dan Rasûl Allah sebagai maha guru (pendidik) dalam keluarga maupun ummatnya, maka keluarga muslim yang dibentuk berdasarkan al-Qur"ean dalam menjalankan proses pendidikannya-baik menyangkut landasan, metode, maupun aturan yang dipergunakannya- tidak lepas dari konsep keluarga yang secara filosofis digali dari teks al-Qur"ân maupun perilaku Rasûl Allah saw. ${ }^{8}$

Selaku orang tua, hampir setiap saat dicekam berbagai kecemasan karena tingkah laku anak-anak nya, acapkali orang tua tidak memahami anak nya sendiri yang kadang-kadang dianggap patuh, tertib, rajin, hormat, akan tetapi kadang-kadang dianggap membangkang, nakal, kurang sopan, malas, dan kurang bergairah belajar. Fenomena ini tentu saja berpangkal pada perlakuan yang pernah diterima anak itu dari orang tua sendiri atau dari lingkungan yang mewarnai hidup dan kehidupan anak itu. ${ }^{9}$ Sebagaimana kita ketahui bahwa ada tiga lingkungan yang bertanggung jawab dalam penyelenggaraan pendidikan, yaitu keluarga (informal), masyarakat (non formal), dan sekolah (formal). Ketiga lingkungan tersebut secara integral bertanggung jawab dalam mendidik anak.

Menurut Hurlock dan Parvin seperti dikutip oleh Syamsu Yusuf mengatakan bahwa keluarga merupakan lingkungan pendidikan pertama dan utama bagi anak. Keluarga berfungsi sebagai "transmitter budaya atau mediator" sosial budaya bagi anak. ${ }^{10}$

Keluarga adalah lingkungan utama dalam pembentukan watak dan karakter masyarakat, juga menjadi lingkungan pertama dimana manusia melakukan komunikasi dan sosialisasi diri dengan manusia lain selain dirinya, serta memiliki tempat dan fungsi yang sangat unik sekaligus dinamis, dan memiliki peran sosial, peran pendidikan sekaligus peran agama Keluarga sebagai lingkungan pertama bagi anak dalam memperoleh pendidikan (agama) dibebankan pada kedua orang tua (Ibu dan bapak). Menurut Ahmad Tafsir, orangtua adalah pendidik utama dan pertama dalam keluarga. Disebut pendidik utama karena besar sekali pengaruhnya. Disebut pendidik pertama karena merekalah yang pertama mendidik anaknya. ${ }^{11}$

Sebagai lembaga pendidikan pertama dan utama, maka orang tua dituntut untuk bertanggung jawab dalam mengajar, membimbing, dan mendidik anak-anak mereka. Proses pendidikan ini dilakukan orang tua mulai anak masih dalam kandungan sampai dewasa. Diantara tanggungjawab orang tua dalam pendidikan yang paling utama bagi anak adalah pendidikan agama, yaitu pendidikan dengan melalui ajaran-ajaran Islam berupa bimbingan dan asuhan-asuhan agar si anak memahami, menghayati dan mengamalkan ajaran Islam, yang mencakup aqidah, syari'ah dan akhlaq. Selanjutnya orang tua dalam memberikan pendidikan agama Islam kepada anak-anaknya perlu memperhatikan aspek-aspek tindakan dan perlakuan orang tua terhadap ajaran agama. Tindakan dan perlakuan orang tua terhadap dirinya dan saudara-saudaranya merupakan unsur-unsur yang akan menjadi bagian pribadinya dikemudian hari. Hal ini dikarenakan fungsi utama keluarga adalah sebagai wahana untuk mendidik, mengasuh, dan mensosialisasikan anak, mengembangkan kemampuan seluruh anggotanya agar dapat menjalankan

\footnotetext{
${ }^{8}$ Suriadi, 'Pendidikan Agama Dalam Keluarga'.

${ }^{9}$ Djawad Dahlan, Pendidikan Keimanan Di Ruman Tangga Bagi Anak Usia 0-5 Tabun, Dalam Pendidikan Agama Dalam Keluarga (Bandung, Indonesia: PT Remaja Rosdakarya, 2003).

10 suriadi, 'Pendidikan Agama Dalam Keluarga'.

11 Ahmad Tafsir.
} 
fungsinya di masyarakat dengan baik, serta memberikan kepuasaan dan lingkungan yang sehat guna tercapainya keluarga, sejahtera. ${ }^{12}$

Tindakan dan perlakuan orang tua yang sesuai dengan ajaran agama, akan menimbulkan pada si anak pengalaman-pengalaman hidup yang sesuai dengan agama, yang kemudian akan bertumbuh menjadi unsurunsur yang merupakan bagian dalam pribadinya nanti. ${ }^{13}$ Untuk itu orang tua diperlukan pemahaman mengenai kandungan pokok ajaran agama Islam yang terdapat dalam alqur'an dan al-hadits yang menjadi sumber pokok ajaran Islam. Mahmud Syaltut seperti dikutip oleh Abdul Latief di dalam bukunya ila alQur'an al-Karim, mengemukakan kandungan pokok al-Qur'an secara garis besar terdiri atas tiga petunjuk, yaitu:

1. Petunjuk tentang aqidah dan kepercayaan yang harus dianut oleh manusia dan tersimpul dalam keimanan akan keesaan Tuhan serta kepercayaan kepastian adanya hari pembalasan.

2. Petunjuk mengenai akhlaq yang murni dengan jalan menerangkan norma-norma keagamaan dan susila yang harus diikuti oleh manusia dalam kehidupan, baik individual maupun kolektif.

3. Petunjuk mengenai syariat dan hukum dengan jalan menerangkan menerangkan dasar-dasar hukum yang harus diikuti oleh manusia dalam hubungannya dengan Tuhan dan sesamanya. ${ }^{14}$

Tipologi kandungan al-Qur'an tersebut pada dasarnya dalam ruang lingkup Pendidikan Islam merupakan materi pendidikan agama Islam yang harus diajarkan pada anak, hal ini tercantum dalam surat luqman ayat 13-19. Selanjutnya untuk mewujudkan maksud-maksud tersebut Al-Qur'an menggunakan metode tertentu.yang mencakup metode-metode sebagai berikut:

a) Metode yang mengajak manusia untuk memperhatikan dan mengkaji segala ciptaan Allah sehingga mengetahui rahasia-rahasia-Nya yang terdapat di alam.

b) Menceritakan kisah umat terdahulu, baik individu maupun kelompok, baik orang-orang yang mengerjakan kebaikan maupun orang-orang yang mengadakan kerusakan, sehingga dari kisah itu manusia dapat mengambil pelajaran tentang hukum sosial yang diberlakukan Allah terhadap mereka.

c) Metode yang menghidupkan kepekaan batin manusia yang mendorongnya untuk bertanya dan berfikir tentang awal dan materi kejadiannya, kehidupannya, dan kesudahannya sehingga insyaf akan Tuhan yang menciptakan segala kekuatan.

d) Metode yang memberikan kabar gembira dan janji serta peringatan dan ancaman. ${ }^{15}$

Pendidikan agama Islam bagi anak dalam keluarga pada dasarnya diarahkan agar anak memiliki nilainilai dasar keimanan, ketaqwaan dan akhlak mulia.

\section{Identifikasi Surat Luqman}

Surat Luqman adalah surah yang turun sebelum Nabi Muhammad saw. berhijrah ke Madinah, Semua ayat-ayatnya Makiyah. Yang demikian merupakan pendapat mayoritas ulama. Namun demikian ada sementara ulama yang mengecualikan tiga ayat yaitu ayat 27-29, atau dua ayat yakni ayat 27 dan 28, dengan alasan bahwa ayat-ayat ini turun berdasarkan diskusi dengan orang-orang Yahudi, yang ketika itu banyak bermukim di Madinah. ${ }^{16}$ Al-Mawardi menerangkan bahwa surat luqman semuanya diturunkan di Makkah, kecuali ayat ke 27 dan 28, menurut riwayat 'Aùo yang mengatakan bahwa dua ayat tersebut diturunkan di

\footnotetext{
12 Suriadi, 'Character Education of Children in the Family', Madaniyah, 9.2, 251-67 <https://journal.stitpemalang.ac.id/index.php/madaniyah/article/view/127>.

13 Zakiah Daradjat, Ilmu Jiwa Agama (Jakarta: Bulan Bintang, 1970).

14 Abdul Latief, Perencanaan Sistem Pengajaran Pendidikan Agama Islam (Bandung, Indonesia: Pustaka Bani Quraisy, 2006).

15 Abdul Latief.

${ }^{16}$ M.Quraish Shihab, Tafsir Al-Misbah,Pesan (Jakarta: Lentera Hati, 2005).
} 
Madinah. Sedangkan menurut al-Hasan kecuali satu ayat yang diturukan di Madinah yaitu ayat ke 4, dengan alasan bahwa perintah salat dan zakat diturunkan di Madinah. ${ }^{17}$

Al-Qurùubî menjelaskan bahwa surat luqman termasuk kelompok surah Makiyah, kecuali ayat ke 27, 28 dan 29. Ketiganya turun di Madinah, Semua ayatnya berjumlah 34 ayat (Al-Qurùubî, t.th). Senada dengan itu Ibnu Kaåîr mengatakan bahwa surat Luqman termasuk surat Makiyah, kecuali ayat ke 27, 28 dan 29, ketiganya diturunkan di Madinah, terdiri dari 34 ayat, diturunkan sesudah surah al-Ėaffât Senada dengan Ibnu Kaåir, Wahbah Zuhaili juga menerangkan bahwa surah Luqmân termasuk surat Makiyah, terdiri dari 34, diturunkan setelah surah al-Èaffât. ${ }^{18}$

Al-Bagdadi menjelaskan bahwa Ibnu al- Æurais, Ibnu Mardawaih dan al-Baihaqi dalam kitab al-Dalâil telah mengeluarkan hadits dari Ibnu 'Abbas ra yang mengatakan bahwa surah Luqman diturunkan di Makah dan tidak ada pengecualian dalam riwayat ini. Adapun dalam riwayat al-Nuhâs dalam kitab Tarihnya mengecualikan tiga ayat yaitu surat 27-29, karena ketiganya diturunkan di Madinah dengan alasan bahwa ketika Rasul Allah saw. berhijrah ke Madinah, pendeta-pendeta Yahudi berkata kepada nya,"Kami telah mendengar suatu berita, bahwasannya engkau telah mengatakan,'Dan tidaklah kamu diberi pengetahuan melainkan sedikit', [QS Al-Isra' (17): 85]. Apakah engkau mengalamatkan perkataan itu pada kami atau kepada kaummu?"Nabi Menjawab,"Aku mengalamatkannya kepada semuanya."Lalu mereka berkata,"Sesungguhnya kamu telah mengetahui, bahwa kami telah diberi kitab Taurat yang di dalamnya terkandung penjelasan segala sesuatu,"Nabi saw. menjawab,"Hal itu menurut ilmu Allah dianggap sedikit."Lalu Allah menurunknh ketiga ayat tersebut. ${ }^{19}$

Menurut perhitungan al-Fairuzabadi bahwa surat Luqman seluruhnya diturunkan di Makah, jumlah ayatnya 34, terdiri dari 748 kata dan 2.110 huruf. Abi Ùâhir Muhammad bin Ya'qûb al-Fairuzabâdî alŠîrâzî, t.th). Dinamai "Luqman" karena pada ayat 12 disebutkan bahwa" Luqmân" telah diberi oleh Allah ni'mat dan ilmu pengetahuan(hikmah), oleh sebab itu dia bersyukur kepada-Nya atas ni'mat yang diberikan itu. Dan pada ayat 13-19 terdapat nasehat Luqmân kepada anaknya. Ini adalah sebagai isyarat dari Allah supaya setiap ibu bapak melaksanakan pula terhadap anak-anak mereka sebagai yang telah dilakukan oleh Luqmân.

Wahbah al-Zuhaili menerangkan bahwa surat tersebut dinamai Luqman karena terkandung didalamnya kisah Luqmân al-Òakîm yang telah memperoleh mutiara hikmah, karena ma'rifat kepada keesaan Allah dan ibadahnya, dan perkara keutamaan akhlak dan adab, serta pencegahannya dari kejelekan dan kemunkaran. ${ }^{20}$ enada dengan itu, al-Qâsimî juga menjelaskan bahwa surat ini dinamakan Luqmân karena didalamnya terkandung kisah Luqmân yang telah memperoleh keutamaan al-hikmah dan rahasia ma'rifah kepada Allah dan sifat-sifat-Nya, dan larangan berbuat syirik, perintah untuk berperilaku dan perperangai terpuji, dan mencegah(melarang) dari perbuatan tercela. Dan ini merupakan tujuan agung dari al-Qur'an. $^{21}$

Hubungan (munasabah) Surat Luqmân dengan surat sebelumnya [al-Rûm] adalah:

1. Dalam surat al-Rûm disebutkan bahwa didalam al-Qur'an Allah membuat banyak tamsil ibarat yang bermanfaat bagi manusia; sedang dalam surat Luqman Allah mengisaratkan yang demikian.

17 Abi al-Òasan Muhammad, Al-Nuktu Wa al-Uyûn Tafsîr al-Mâwardî (Beirut: Dâr al-Kutub al'Ilmiah, t.th).

18 Al-Imam al-Jalil al-Hafiz Abu al-Fidâ Isma'îl Ibnu Kaâîr al-Qursyi al-Dimasqi, Tafsîr Al-Qur'an al'Aì̀m, Terj. Bahrun Abu Bakar (Bandung, Indonesia: Sinar Baru Algensindo, 2006).

${ }^{19}$ Abi al-Fadli Syihab al-Din al-Sayid Mahmud al-Alusi al-Bagdadi, Rûh Al-Ma'ânî Fî Tafsîr al-Qur'ân al'Aì̀m Wa al-Sab’i al-Maâan̂̀ (Beirut: Daral-Kutub Ilmiyah, 1992).

${ }^{20}$ Wahbah al-Zuhaili, Al-Tafsîr al-Munîr Fî al-'Aqîdah Wa al-Ėarî'Ah Wa al-Manhaj (Damsyik: Dâr al-Fikr, t.th).

${ }^{21}$ Muhammad Jamâl al-Dîn al-Qâsimî, Tafsîr Al-Qâsimi al-Musammâ Mâhasin al Ta'wîl (Beirut: Dar al-Fikr, t.th). 
2. Pada bagian akhir surat al-Rûm disebutkan bahwa keadaan orang kafir itu bila dibacakan kepada mereka ayat-ayat al-Qur'an mereka selalu membantah dan mendustakannya, sedang pada bahagian permulaan surat Luqmân Allah diterangkan keadaan mereka yaitu mereka selalu berpaling dan bersifat sombong terhadap ayat-ayat al-Qur'an itu.

3. Pada surat al-Rûm terdapat ketegasan bahwa Allah lah yang memulai penciptaan makhluk dan Dia pulalah yang menciptakannya pada kali yang kedua. Hal itu amat mudah bagi-Nya. Dalam surat Luqmân Allah menegaskan bahwa penciptaan manusia dan membangkitkannya kembali di akhirat adalah mudah bagi Allah.

4. Pada surah al-Rûm Allah menerangkan tabi'at manusia bahwa apabila mereka ditimpa bahaya mereka berserah diri kepada Tuhannya dan bila mendapat rahmat sebagian dari mereka kembali mempersekutukan-Nya. Dalam surat Luqmân diterangkan tentang watak manusia itu dengan memberikan contoh yaitu ketika manusia ditimpa bahaya di tengah lautan, dan ketika mereka telah selamat sampai di darat.

Adapun hubungan (munasabah) surat Luqmân dengan surat sesudahnya [al-Sajdah] adalah:

1. Kedua surat ini sama-sama menerangkan dalil-dalil dan bukti-bukti ke-esaan Allah.

2. Dalam surat Luqman disebutkan keingkaran kaum musyrikin terhadap Al-Qur'an, sedang surat alSajdah menegaskan bahwa al-Qur'an itu sungguh-sungguh diturunkan dari Tuhan.

3. Dalam surat Luqman ayat 34 disebutkan bahwa ada lima hal yang gaib yang hanya Allah saja mengetahuinya, sedang dalam surat al-Sajdah Allah menerangkan dengan lebih luas hal-hal yang berhubungan dengan yang gaib itu (lihat ayat $5 \mathrm{~s} / \mathrm{d} 27$ surat al-Sajdah).

Tema Utama dari surah Luqmân menurut thabâthabâi dan Sayyid Quthub seperti diterangkan oleh Quraish Shihab adalah ajakan kepada tauhid dan kepercayaan akan keniscayaan kiamat serta pelaksanaan prinsip-prinsip dasar agama. Menurut al-Biqa'i bahwa tujuan utama surah ini adalah membuktikan betapa kitab al-Qur'an mengandung hikmah yang sangat dalam, yang mengantar kepada kesimpulan bahwa yang menurunkannya adalah Dia Yang Maha Bijaksana dalam firman dan perbuatan-perbuatan-Nya. ${ }^{22}$

Adapun Nurwajah Ahmad E.Q, mengemukakan bahwa pokok-pokok ajaran yang terkandung dalam surah tersebut terdiri dari: pertama, keimanan kepada Allah, para Nabi dan hari kiamat. Terkait dengan keimanan kepada Allah dijelaskan pula kekuasaan Allah, meliputi apa yang ada di langit dan di bumi, perputaran malam dengan siang dan lima masalah gaib yang pengetahuan akan hal tersebut hanyalah milik Allah. Kedua, kisah Luqmân merupakan potret orang tua dalam mendidik anaknya dengan ajaran keimanan, dengan pendidikan persuasife Luqmân dianggap sebagai profil pendidik bijaksana sehingga Allah mengabadikannya dalam al-Qur'an dengan tujuan agar menjadi ibrah bagi para pembacanya, Ketiga, karakteristik manusia pembangkan. Allah menjelaskan tipe manusia pembangkang terhadap perintahnyaNya sehingga pada akhirnya mereka tidak mau mendengarkan al-Qur'an. ${ }^{23}$

Dengan demikian dapat disimpulkan bahwa Surat Luqmân adalah surat ke tigapuluh satu dari alQur'an, yang diturunkan setelah surat al-Ėaffât, keseluruhan ayat diturunkan di Makkah. Ada diantara para ulama yang mengecualikan, yaitu ayat 27, 28, dan 29 ketiganya diturunkan di Madinah. Dinamakan surah Luqmân karena di dalamnya mengandung kisah Luqmân al-Òakîm, seorang hamba saleh yang telah diberi keutamaan al-Hikmah oleh Allah sehingga ia bersyukur kepada Allah karena karunia tersebut.

Dan (Ingatlah) ketika Luqman Berkata kepada anaknya, di waktu ia memberi pelajaran kepadanya: "Hai anakku, janganlah kamu mempersekutukan Allah, Sesungguhnya mempersekutukan (Allah) adalah benar-benar kezaliman yang besar".

14. Dan kami perintahkan kepada manusia (berbuat baik) kepada dua orang ibu- bapanya; ibunya Telah mengandungnya dalam keadaan lemah yang bertambah- tambah, dan menyapihnya dalam dua tahun. Bersyukurlah kepadaku dan kepada dua orang ibu bapakmu, Hanya kepada-Kulah kembalimu.

22 M.Quraish Shihab.

${ }^{23}$ Nurwadjah Ahmad E.Q, Tafsir Ayat-Ayat Pendidikan (Bandung, Indonesia: Marja, 2007). 
15. Dan jika keduanya memaksamu untuk mempersekutukan dengan Aku sesuatu yang tidak ada pengetahuanmu tentang itu, Maka janganlah kamu mengikuti keduanya, dan pergaulilah keduanya di dunia dengan baik, dan ikutilah jalan orang yang kembali kepada-Ku, Kemudian Hanya kepada-Kulah kembalimu, Maka Kuberitakan kepadamu apa yang Telah kamu kerjakan.

16 (Luqman berkata): "Hai anakku, Sesungguhnya jika ada (sesuatu perbuatan) seberat biji sawi, dan berada dalam batu atau di langit atau di dalam bumi, niscaya Allah akan mendatangkannya (membalasinya). Sesungguhnya Allah Maha Halus lagi Maha Mengetahui.

17. Hai anakku, Dirikanlah shalat dan suruhlah (manusia) mengerjakan yang baik dan cegahlah (mereka) dari perbuatan yang mungkar dan Bersabarlah terhadap apa yang menimpa kamu. Sesungguhnya yang demikian itu termasuk hal-hal yang diwajibkan (oleh Allah).

18. Dan janganlah kamu memalingkan mukamu dari manusia (karena sombong) dan janganlah kamu berjalan di muka bumi dengan angkuh. Sesungguhnya Allah tidak menyukai orang-orang yang sombong lagi membanggakan diri.

19. Dan sederhanalah kamu dalam berjalan dan lunakkanlah suaramu. Sesungguhnya seburuk-buruk suara ialah suara keledai.

\section{Implikasi Surah Luqman terhadap Pendidikan dalam Keluarga}

Kalau dikaji dari sisi redaksi surat Luqmân ayat 13-19, secara keseluruhan isi dari pendidikan agama yang dilakukan oleh Luqmân berisi sembilan perintah, tiga larangan dan tujuh ta'lilah (argumentasi). Kesembilan perintah tersebut meliputi; 1) berbuat baik kepada orang tua, 2) syukur kepada Allah dan orang tua, 3) berkomunikasi yang baik dengan orang tua, 4) mengikuti pola hidup anbiya dan shalihin, 5) menegakkan salat, 6) amar ma'ruf, 7) nahi munkar, 8) sederhana dalam kehidupan, 9) bersikap sopan dalam berkomunikasi. ${ }^{24}$

Adapun yang berbentuk larangan adalah; 1) larangan melakukan perbuatan syirik, 2) larangan bersikap sombong, dan 3) larangan berlebihan dalam kehidupan. Sedangkan ketujuh argumentasi (ta'lilah) itu adalah; 1) barang siapa bersyukur, sungguh syukurnya itu untuk dirinya sendiri, dan barang siapa kufur, sesungguhnya Allah Maha Kaya dan Maha Terpuji. 2) sesungguhnya syirik itu merupakan kezaliman yang besar. 3) kepada Allah manusia akan dikembalikan, untuk mempertanggung jawabkan apa yang telah diperbuatnya selama hidup di dunia. 4) sesungguhnya Allah Maha Mengetahui segala sesuatu, 5) sesungguhnya semuanya itu merupakan 'azm al-umur, 6) sesungguhnya Allah tidak menyukai orang yang sombong, 7) sesungguhnya sejelek-jeleknya suara adalah suara keledai. Menurut hemat penulis bahwa isi atau materi pokok pendidikan agama yang dilaksanakan Luqman terhadap anaknya pada ayat 13-19 tersebut diatas mencakup tiga aspek penting ajaran Islam, yaitu meliputi aspek; 1). Pendidikan Aqidah, 2) Pendidikan Ibadah dan 3) Pendidikan Akhlaq.

1. Pendidikan Aqidah

Ada tiga aspek penting dalam penanaman aqidah agama yang dilakukan Luqman kepada anak nya, yaitu: 1). Keyakinan tauhid yang sebersih-bersihnya yaitu larangan mempersekutukan Allah, 2). Kesadaran akan kemakhlukan kita yang wajib mensyukuri segala karunia Tuhan, dan 3). Kesadaran bahwa segala gerak-gerik kita yang nampak maupun yang tersembunyi tidak lepas dari pengetahuan dan pengawasan Tuhan.

\footnotetext{
${ }^{24}$ Nurwadjah Ahmad E.Q.
} 
Pendidikan aqidah berupa larangan mensyarikatkan Allah swt. termuat dalam ayat yang berbunyi: "Dan (Ingatlah) ketika Luqman Berkata kepada anaknya, di waktu ia memberi pelajaran kepadanya: "Hai anakku, janganlah kamu mempersekutukan Allah, Sesungguhnya mempersekutukan (Allah) adalah benarbenar kezaliman yang besar"." (QS Luqman [31]: 13)

Menurut al-Maragi, Luqman menjelaskan kepada anaknya, bahwa perbuatan syirik itu merupakan kezaliman yang besar. Syirik dinamakan perbuatan zalim, karena meletakkan sesuatu bukan pada tempatnya. ${ }^{25}$ Dan itu dikatakan dosa besar, karena perbuatan itu berarti menyamakan kedudukan Tuhan yang hanya dari Allah lah segala nikmat- dengan sesuatu yang tidak memiliki nikmat apapun, yaitu berhala-berhala. Imam Bukhari telah meriwayatkan sebuah hadits yang bersumber dari Ibnu Mas'ud ra. yang mengatakan bahwa ketika ayat ini diturunkan, yaitu firman-Nya:

"Orang-orang yang beriman dan tidak mencampuradukkan iman mereka dengan kezaliman (syirik), mereka Itulah yang mendapat keamanan dan mereka itu adalah orang-orang yang mendapat petunjuk." (QS Luqman [31] : 13). Maka hal itu dirasakan sangat berat oleh para sahabat, lalu mereka berkata, "Siapakah diantara kita yang tidak mencampuradukkan imannya dengan perbuatan zalim(dosa)?" Maka Rasul Allah saw. menjawab, "Sesungguhnya pengertian zalim itu tidaklah demikian, tidakkah kalian pernah mendengar perkataan Luqman?”. (Al-Maragi, 2006)

Saleh Fauzan seperti dikutip Nurwajah mendefinisikan syirik dengan penyimpangan dalam ibadah kepada Allah. Syirik terbagi menjadi dua macam: pertama, syirik akbar yakni yang dapat mengeluarkan seseorang dari Islam; dan kedua, syirik ashgar, yakni penyimpangan dalam perilaku ibadah. Larangan syirik yang disertai ancaman merupakan keharusan hanya taat dan bertauhid kepada Allah. Larangan berbuat syirik diungkapkan dengan fi'l al-mudhari' yang mengindikasikan li al-istimrar, dalam arti, sejak dini para pendidik harus menciptakan lingkungan yang kondusif agar terbebas dari situasi dan kondisi yang menjerumuskan pada kemusyrikan, serta mendorong anak didiknya agar terus menerus mencari ilmu (Nurwadjah Ahmad, 2007).

Pada ayat ini, Luqman memberikan pendidikan dan pengajaran kepada anaknya berupa aqidah yang mantap, agar tidak mensekutukan Allah. Itulah aqidah tauhid, karena tidak ada Tuhan selain Allah, karena yang selain Allah adalah makhluk. Allah tidak berserikat di dalam penciptaan alam ini. Orang yang mempersekutukan Allah adalah berarti telah melakukan suatu aniaya yang besar, bahkan dosa yang paling besar yang tidak ada ampunan dari Allah walau ia bertaubat, karena pada dasarnya Allah mengajak manusia agar membebaskan jiwa dan keyakinannya dari segala sesuatu selain Allah. Jiwa manusia adalah mulia, sebab itu hubungan manusia haruslah langsung kepada Allah. Jiwa manusia yang dipenuhi tauhid adalah jiwa yang merdeka, tidak ada yang dapat mengikat jiwa itu kecuali hanya dengan Allah. Bila manusia telah mempertuhankan yang lain, padahal yang lain itu hanyalah makhluk belaka, maka manusia sendirilah yang membawa jiwanya menjadi budak oleh makhluk lain. ${ }^{26}$

Ayat ini mendidik manusia bahwa keyakinan pertama dan utama yang perlu ditanamkan dan diresapkan kepada anak adalah tauhid. Kewajiban ini terpikul kepundak orang tua sebagai pendidik awal dalam pendidikan informal. Tujuannya adalah agar anak terbebas dari perbudakan materi dan duniawi, sehingga keyakinannya mantap dan akidahnya kokoh, serta keyakinan itu perlu diresapkan sedini mungkin disaat anak telah mulai banyak bertanya kepada orang tuanya.

Tidak ada bekal yang paling berharga dari seorang ayah kepada anaknya yang akan menjauhkan anaknya dari kerusakan besar serta menyelamatkannya di dunia dan akhirat, kecuali pendidikan tauhid atau larangan berbuat syirik.

${ }^{25}$ Maragi, Tafsir Al-Maragi, Terj. Bahrun Abu Bakar (Semarang: Toha Putra, 1992).

${ }^{26}$ Abdul Latief. 
Perintah supaya mensyukuri segala nikmat pemberian Allah swt., termasuk perintah supaya mensyukuri atas pengorbanan dan perjuangan orang tua yang telah mengandung, melahirkan, menyapih, membimbing dan mendidik anak-anaknya, sehingga anak wajib berbakti dan taat kepada Ibu bapaknya. Hal ini dijelaskan dalam ayat ke 14 yang berbunyi: "Dan kami perintahkan kepada manusia (berbuat baik) kepada dua orang ibu- bapanya; ibunya Telah mengandungnya dalam keadaan lemah yang bertambahtambah, dan menyapihnya dalam dua tahun. Bersyukurlah kepadaku dan kepada dua orang ibu bapakmu, Hanya kepada-Kulah kembalimu."

Al-Maragi dalam tafsirnya menjelaskan, "Dan Kami perintahkan kepadanya, bersyukurlah kamu kapada-Ku atas semua nikmat yang telah Kulimpahkan kepadamu, dan bersyukur pulalah kepada kedua ibu bapakmu.Karena sesungguhnya keduanya itu merupakan penyebab bagi keberadaanmu. Dan keduanya telah merawatmu dengan baik, yang untuk itu keduanya mengalami berbagai macam kesulitan sehingga kamu menjadi tegak dan kuat." 27

Pada Ayat ini Tuhan memerintahkan kepada manusia agar mereka menghormati, memuliakan dan berbuat baik kepada ibu bapaknya, sebab karena keduanyalah manusia dilahirkan ke dunia ini. Oleh karena itu sudah sewajarnya jika keduanya dihormati dan dimuliakan. Apalagi terhadap ibu yang sudah bersusah payah mengandung nya selama sembilan bulan dengan segala kepayahannya dan puncak kepayahan itu ketika ibu melahirkan anaknya. Setelah lahir, maka kewajiban orang tua khususnya ibu ialah mengasuh, menyusui, menyapihnya hingga usia dua tahun. Dalam proses membesarkan anak, peran ibu lebih banyak daripada ayah. Maka berbakti kepada ibu juga melebihi tiga kali lipat dari ayah. Pendidikan aqidah tentang berupa kesadaran akan muraqabullah (merasa di awasi oleh Allah atas segala gerak gerik kita) dijelaskan dalam ayat ke 16 yang berbunyai:"(Luqman berkata): "Hai anakku, Sesungguhnya jika ada (sesuatu perbuatan) seberat biji sawi, dan berada dalam batu atau di langit atau di dalam bumi, niscaya Allah akan mendatangkannya (membalasinya). Sesungguhnya Allah Maha Halus, lagi Maha Mengetahui."

Ibnu Katsir berkata: "Sekalipun perbuatan tersebut seberat bijisawi, tersembunyi dan tertutup di dalam batu besar, atau di dalam hutan belantara di kolong langit dan bumi, maka sesungguhnya Allah akan mendatangkannya (membalasnya). Karena bagi Allah tidak ada yang tersembunyi daripada-Nya seberat zarrah pun baik yang ada di langit atau yang ada di bumi. Itulah sebabnya Allah berfirman," Sesungguhnya Allah Maha Halus lagi Maha Mengetahui." Yaitu halus dan mengetahui, tidak ada sesuatu apapun yang tersembunyi sekalipun ia kecil dan halus. "Maha mengetahui" meskipun dengan rayapan semut di kegelapan malam yang gelap gulita. ${ }^{28}$

Ayat ini menjelaskan tentang kebesaran ilmu Allah dan keesaan-Nya, dan tentang ilmu-Nya yang meliputi semua makhluk ciptaan, tidak ada sesuatupun di langit dan bumi yang lepas dari pengawasan-Nya. Pada ayat ini dijelaskan seakan-akan Luqman mengatakan kepada putranya,"Janganlah kamu mengira bahwa kamu dapat menyembunyikan diri dari pengamatan Allah swt. atau melepaskan diri dari kekuasaanNya. Jika kamu hendak berbuat dosa atau maksiyat, sesungguhnya Allah swt. melihatmu dan tidak ada sesuatu yang bisa luput dari pandangan kekuasaan-Nya.

Penanaman aqidah semacam ini amatlah penting dilakukan oleh orang tua terhadap anaknya, dan harus diberikan sejak sedini mungkin. Menurut Zakiyah Darajat bahwa pendidikan keimanan (aqidah) yang tangguh, seharusnya dimulai dalam keluarga, sejak sianak lahir, bahkan sejak sebelum lahir (prenatal), sampai akhir masa remaja. Apabila pendidikan keimanan terabaikan di dalam keluarga, terutama sampai akhir masa kanak-kanak (12 tahun),akan sulitlah bagi anak dalam menghadapi perubahan cepat pada dirinya, yang tidak jarang membawa kegoncangan emosi. ${ }^{29}$ Dari luar sianak akan menghadapi pengaruh yang dibawa oleh alat-alat komunikasi, baik media elektronik maupun media cetak dan hubungan langsung

27 Maragi.

28 Al-Imam al-Jalil al-Hafiz Abu al-Fidâ Isma'îl Ibnu Kaåîr al-Qursyi al-Dimasqi.

29 Zakiah Daradjat. 
yang dibawa oleh tamu-tamu manca negara yang mempunyai kebudayaan dan cara hidup yang tidak sejalan dengan budaya kita bahkan mungkin bertentangan dengan ajaran yang kita anut. Selain ketiga hal pokok di atas perlu penulis kemukakan tentang materi pendidikan aqidah bagi anak di lingkungan keluarga. Menurut Muhammad Nur Abdul Majid dalam rangka pendidikan aqidah yang benar kepada anak, setidaknya ada lima pola dasar pendidikan aqidah yang harus dilakukan orang tua, yaitu: 1) mendiktekan/membacakan kalimat tauhid, 2) menanamkan cinta kepada Allah swt. 3) menanamkan cinta kepada Rasul Allâh. 4) mengajarkan al-Qur'an dan 5) menanamkan nilai-nilai perjuangan dan pengorbanan. ${ }^{30}$

Senada dengan itu, dalam upaya membimbing dan mengarahkan anak kedalam aqidah yang benar dapat ditempuh dengan: a) membangkitkan potensi fitrah anak, b) memperkenalkan nikmat-nikmat Allah, c) menanamkan perasaan muraqabatullah (merasa dipantau oleh Allah), d) mengajarkan al-Qur'an dan e) mengajarkan kalimat tauhid. f) menanamkan rasa cinta kepada Allah. g) menanamkan rasa cinta kepada Rasul Allah, h) menanamkan rasa cinta kepada Sahabat Rasul, i) menanamkan rasa cinta kepada orang tua. $^{31}$

\section{2). Pendidkan Ibadah (Syari'ah)}

Setelah Luqman mengawali pendidikan dan pengajaran kepada putranya berupa pendidikan aqidah, maka ia melanjutkan pemberian pendidikannya pada aspek ibadah. Pendidikan ibadah mencakup segala tindakan dalam kehidupan sehari-hari, baik yang berhubungan dengan Allah (habl min Allah) maupun dengan sesama manusia (habl min al-Nas) Hubungan dengan Allah swt. yang terbesar sesudah tauhid adalah mendirikan shalat. Jadi untuk menumbuhkan, memupuk dan memantapkan keyakinan agama itu, maka Luqman memerintahkan kepada anaknya agar mendirikan shalat. Ini berarti melaksanakan ibadah harus dibiasakan semenjak kecil.

Perintah ini dinyatakan dalam ayat 17 , yang berbunyi: "Hai anakku, dirikanlah shalat dan suruhlah (manusia) mengerjakan yang baik dan cegahlah (mereka) dari perbuatan yang mungkar dan bersabarlah terhadap apa yang menimpa kamu. Sesungguhnya yang demikian itu termasuk hal-hal yang diwajibkan (oleh Allah)." Ibnu Katsir berkata: "Dirikanlah shalat yaitu dengan semua ketentuannya, kewajibannya, dan waktunya, mengajak kepada kebaikan dan mencegah dari kemungkaran sebatas kemampuan dan usahamu. Bersabarlah terhadap apa yang menimpa kamu. Karena mengajak kepada kebaikan dan mencegah dari kemunkaran pasti mengalami penyiksaan dari orang lain, sehingga ia diperintahkan untuk bersabar. Firman Allah,"Sesungguhnya yang demikian itu termasuk hal-hal yang diwajibkan (oleh Allah)." Yaitu, bahwa bersabar atas kejahatan manusia termasuk hal-hal yang diwajibkan oleh Allah. ${ }^{32}$

Seseorang diperintah bersabar atas kesulitan dunia seperti sakit dan lainnya, agar ia tidak keluar dari kesulitan dengan melakukan kemaksiatan kepada Allah. Selanjutnya al-Qurtubi berkata,"Secara zhahir firman Allah,"Sesunggunya yang demikian," menunjukkan kepada mendirikan shalat, mengajak kepada kebaikan dan mencegah dari kemunkaran, bersabar atas penderitaan dan musibah, dan semuanya merupakan hal-hal yang diwajibkan oleh Allah.

Wahbah Zuhaili seperti dikutip Nurwadjah menjelaskan bahwa penegakan nilai-nilai shalat dalam kehidupan merupakan manifestasi dari ketaatan kepada Allah. Shalat merupakan komunikasi hamba dan khaliknya, semakin kuat komunikasi tersebut, semakin kuat keimanannya. Demikian pula dengan amar ma'ruf nahi munkar, ia merupakan wujud kepedulian terhadap keselamatan sesama. Upaya amar ma'ruf

\footnotetext{
${ }^{30}$ Maulana Muhammad Ali, Islamologi (Jakarta: PT Ikhtiar Baru, 1980).

${ }^{31}$ Nurwadjah Ahmad E.Q.

32 Al-Imam al-Jalil al-Hafiz Abu al-Fidâ Isma'îl Ibnu Kaåîr al-Qursyi al-Dimasqi.
} 
membutuhkan stamina yang kuat, sebab ia mengundang resiko cukup berat. Oleh karena itu pada bagian akhir ayat ini ada perintah bersabar dalam kondisi apapun dan jangan keluar dari taat kepada Allah. ${ }^{33}$

Ayat ini menurut hemat penulis secara implisit dan eksplisit menjelaskan bahwa kewajiban orang tua selaku pendidik dalam keluarga untuk memberikan pendidikan tentang shalat dengan memberikan bimbingan, arahan, ketentuan-ketentuan yang berkaitan dengan pelaksanaan ibadah shalat- juga menyuruh anak-anak untuk melakukan perbuatan-perbuatan yang baik (amar ma'ruf) dan menjauhi perbuatanperbuatan yang buruk (nahi munkar) serta mendidik mereka agar untuk berlaku bersabar dalam menghadapi segala ujian, cobaan dan musibah yang menimpanya, terutama bersabar dari perbuatanperbuatan orang yang merasa tidak senang dengan ajakan kebaikan kita. Didikan yang diberikan kepada anak tentu saja tidak sekadar bersifat pengetahuan tentang apa yang ma'ruf dan apa yang munkar, tetapi terutama diarahkan pada hal-hal yang bersifat membangkitkan: 1) tekad untuk menegakkan hal-hal yang ma'ruf dan mencegah hal-hal yang munkar, 2) keberanian untuk menanggung resiko dalam menegakkan hal-hal yang ma'ruf dan mencegah hala-hal yang munkar.

Materi pendidikan yang dilakukan oleh Luqman ini mengindikasikan kepada orang tua agar melakukan hal yang sama terhadap anak-anaknya agar kesemuanya itu harus dimengerti, dipahami, dihayati dan dikerjakan oleh anak-anak dalam kehidupan sehari-hari.

\section{3) Pendidikan Akhlak}

Materi pendidikan akhlak pada surat Luqman dapat dilihat pada ayat ke 14,15, 18 dan 19.

Pada ayat ke 14 dan 15 menjelaskan kepada kita bahwa orang tua telah bersusah payah dalam mengasuh anak-anaknya, terlebih lagi adalah ibu. Yang telah bersusah payah mengandung anak nya selama sembilan bulan dan menyapihnya hingga usia dua tahun. Maka Allah memerintahkan agar seorang anak harus bersukur kepada Allah yang telah memberikan segala nikmat-Nya dan bersyukur (berterima kasih) kepada orang tua yang menjadi sebab kehadirannya di dunia ini.

Inti dari pendidikan akhlak pada ayat ini adalah agar anak berlaku sopan santun, bertutur kata yang lemah lembut, bergaul dengan penuh kasih sayang, mentaati segala perintahnya selagi perintah mereka tidak menyuruh pada perbuatan yang melanggar agama. Dan jika orang tua mereka berlainan kepercayaan, maka bagi anak tidak wajib mengikuti kepercayaan orang tuanya akan tetapi harus tetap menggaulinya di dunia ini dengan penuh kasih sayang.

Pendidikan akhlak selanjutnya diarahkan pada etika bergaul dengan masyarakat. Hal ini terdapat pada ayat ke 18 dan 19, yang berbunyi: "Dan janganlah kamu memalingkan mukamu dari manusia (karena som mbong) dan janganlah kamu berjalan di muka bumi dengan angkuh. Sesungguhnya Allah tidak menyukai orang-orang yang sombong lagi membanggakan diri. Dan sederhanalah kamu dalam berjalan dan lunakkanlah suaramu. Sesungguhnya seburuk-buruk suara ialah suara keledai." (QS Luqman [31]: 18-19)

Menurut Qurash Shihab, ayat ini mendidik manusia berkaitan dengan akhlak dan sopan santun berinteraksi dengan sesama manusia. ${ }^{34}$ (Materi pelajaran aqidah, beliau selingi dengan materi pelajaran akhlak, bukan saja agar peserta didik tidak jenuh dengan satu materi, tetapi juga untuk mengisyaratkan bahwa ajaran akidah dan akhlak merupakan satu kesatuan yang tidak dapat dipisahkan. Luqman mengajarkan kepada putranya untuk tidak memalingkan pipinya dari manusia siapa pun dia- didorong oleh penghinaan dan kesombongan. Tetapi tampillah kepada setiap orang dengan wajah berseri penuh rendah hati. Dan bila melangkahkan kaki, janganlah berjalan dimuka bumi dengan angkuh, tetapi berjalanlah

${ }^{33}$ Nurwadjah Ahmad E.Q.

${ }^{34}$ Shihab and Ali-Fauzi. 
dengan lemah lembut penuh wibawa. Sesungguhnya Allah tidak menyukai yakni jangan membusungkan dada dan jangan juga merunduk bagaikan orang sakit. Jangan berlari tergesa-gesa dan jangan juga sangat perlahan menghabiskan waktu. Dan lunakkan suaramu sehingga tidak terdengar kasar bagaikan teriakan keledai. Sesungguhnya seburuk-buruk suara ialah suara keladai karena awalnya siulan yang tidak menarik dan akhirnya tarikan nafas yang buruk. ${ }^{35}$

Sedangkan menurut Wahbah Zuhaili seperti dikutip Nurwadjah mengatakan bahwa ayat tersebut mengandung larangan terhadap sikap takabur di hadapan orang lain, lantaran sikap tersebut merupakan wujud manusia musyrik, bukan hamba yang syakur. Pada ayat 18 larangan takabur lebih ditekankan pada hati, sedangkan ayak ke 19 lebih kepada perilaku yang nampak di lapangan. Waqèid fí mašyika mempunyai makna sederhana dalam hidup dan kehidupan; sedangkan Wagæuæ min èautik mempunyai arti menghargai orang lain dengan cara berkomunikasi secara baik. ${ }^{36}$ Menurut hemat penulis bahwa berdasarkan ayat tersebut di atas ada beberapa pendidikan akhlak yang dikemukakan oleh Luqman:

1. Larangan memalingkan muka ketika berbicara dengan orang lain. Kalau seseorang sedang berbicara berhadapan dengan orang lain hendaklah berhadapan muka, sebab berhadapan muka sebagai pertanda berhadapan hati, karena dengan demikian akan tersinggung perasaan lawan bicara, dirinya tidak dihargai, dan perkataannya tidak sempurna didengarkan. Jangan sampai memalingkan muka dari orang lain karena sombong, ujub dan menghina mereka. Pandangilah dengan penuh perhatian dan kasih sayang apabila yang berbicara anak kecil sehingga ia menyelesaikan pembicaraannya. Orang yang bersikap memalingkan muka dari orang lain akan menyebabkan ia dibenci oleh orang lain dan tidak akan dihargai serta menyebabkan dirinya terkucil dari pergaulan dengan sesamanya, dan ini termasuk dalam akhlak tercela.

2. Larangan berjalan dengan angkuh dan sombong. Luqman mendidik putranya agar tidak memiliki akhlak tercela, seperti berjalan dengan sikap angkuh. Sebab orang yang angkuh selalu sombong dan membanggakan diri ketika berjalan. Perilaku seperti ini akan menimbulkan kebencian dan permusuhan orang lain yang memandangnya.

3. Sederhana dalam hidup dan kehidupan. Luqman mendidik putranya agar menjalani hidup dan khidupan ini dengan penuh kesederhanaan. Hidup yang wajar dan sederhana $m$ tidak menunjukkan kemewahannya jika ia orang kaya dan tidak terlalu menunjukkan kehinaannya kalaupun ia hidup miskin. Digambarkan disana kalau berjalan dengan langkah yang sederhana, yakni tidak terlalu cepat juga tidak terlalu lambat. Akan tetapi hendaklah yang wajar-wajar saja, tidak dibuat-buat, dan juga tanpa pamer menonjolkan sikap rendah diri atau tawadlu. Jadi sikap seseorang itu hendaklah wajarwajar saja, terutama ketika sedang berjalan.

4. Bertutur kata yang lemah lembut. Luqman juga mengajarkan putranya etika sopan santun dalam berbicara Nasehatnya mengarahkan pada putranya agar memiliki etika dalam berkomunikasi dengan orang lain. Berbicara dengan orang lain harus dilakukan dengan menggunakan bahasa komunikasi yang dapat dimengerti oleh keduanya sehingga tidak terjadi kesalah fahaman dan cepat dimengerti serta dengan suara yang wajar, tidak terlalu keras juga tidak terlalu rendah. Dalam berkomunikasi kita bisa menggunakan berbagai bentuk komunikasi yang baik, dan bentuk-bentuk ini banyak dikemukakan dalam al-Quran, seperti; perkataan yang mulia (qaulan kariman) QS al-Isra'[17]: 23; perkataan yang baik (qaulan ma'rûfan) QS al-Nisâ' [4]: 5, 8; perkataan yang benar(qaulan sadîdan) QS al-Nisâ' [4]: 9; perkataan lemah lembut (qaulan layyinan) QS U̇âhâ [20]: 44 dan ucapan yang pantas (qaulan maesûran) QS al-Isra' [17]: 28; Perkataan yang berat (qaulan tsaqilan) QS al-Muzammil [73]: 5. Selanjutnya perlu penulis tekankan disini bahwa materi Pendidikan Agama yang telah dilakukan oleh Luqman telah mencakup aspek-aspek dasar dari ajaran Islam, yaitu aspek aqidah, syari'ah (ibadah) dan akhlak. Dan yang perlu digaris bawahi bahwa pendidikan agama bagi anak-anak, tidak hanya ditekankan pada segi penguasaan hal-hal yang bersifat kognitif atau pengetahuan tentang ajaran agama atau ritus-ritus keagamaan semata. Justru yang lebih penting, ialah menanamkan nilai-nilai keagamaan dan membuatnya terwujud nyata dalam tingkah laku dan budi pekerti sehari-hari.

Berdasarkan uraian di atas penulis berkesimpulan bahwa Luqman telah melakukan kegiatan berupa menanamkan dimensi hidup Ketuhanan atau jiwa rabbaniyyah pada putranya. Jika dicoba untuk merinci wujud nyata atau substansi dari jiwa Ketuhanan itu, maka kita dapatkan nilai-nilai keagamaan pribadi

35 Shihab and Ali-Fauzi.

${ }^{36}$ Nurwadjah Ahmad E.Q. 
yang amat penting yang sangat mendasar dan yang harus ditanamkan kepada anak. Diantara nilai-nilai yang sangat mendasar itu adalah: Iman, Islam, Ihsan, TakwaI, ikhlash, tawakallah, syukur dan shabar. Selanjutnya bahwa selain pendidikan akhlak yang disebut pada ayat-ayat tersebut di atas, penulis perlu menambahkan materi pendidikan akhlak bagi anak di dalam keluarga yang menurut Nurchlolis Majid perlu dipertimbangkan oleh orang tua. ${ }^{37}$

Adapun nilai-nilai akhlak tersebut adalah; 1) silaturrahmi, 2) persaudaraan(al-ukhuwwah), 3) persamaan (al-musawah), 4) 'adil ('adalah), 5) baik sangka (husnu al-ìan) 6) rendah hati(tawaææu'), 7)tepat janji (al-wafa), 8) lapang dada (inširah), 9) dapat dipercaya (al-amanah), 10)perwira ('iffah), 11) hemat (qawamiyah), dan dermawan (al-munfiqun).

\section{Simpulan}

Pelaksanaan pendidikan Agama Islam bagi anak di dalam lingkungan keluarga sangat penting untuk diperhatikan oleh orang tua, kewajiban itu terpikul dipundak kedua orang tua. Sangat tidak benar seandainya orang tua menyerahkan pendidikan Agama bagi anak-anaknya kepada sekolah atau guru ngaji saja. Karena proses pembinaan keberagamaan anak akan lebih banyak berada di dalam keluarga, dan itu membutuhkan pengawasan langsung dari orang tua. Orang tua perlu menambah ilmu pengetatahuan agamanya sehingga memiliki modal untuk dapat memberikan pendidikan keagamaan kepada anakanaknya.

Materi pokok pendidikan Agama Islam yang harus ditanamkan (dididikkan) kepada anak-anak di dalam lingkungan keluarga terdapat pada surah Luqman ayat 13-19. Karena dalam surah Luqman ayat 1319 tersebut sudah mencakup tiga aspek ajaran Islam, yaitu Aqidah, ibadah dan Syari'ah. Pada Aspek pendidikan Aqidah meliputi hal-hal pokok yaitu; a) Keimanan (pengeesaan) kepada Allah swt, keyakinan tauhid yang sebersih-bersihnya yaitu larangan mengsekutukan Allah, b) Kesadaran akan kemakhlukan kita yang wajib mensyukuri segala karunia Tuhan, dan c Kesadaran bahwa segala gerak-gerik kita yang nampak maupun yang tersembunyi tidak lepas dari pengetahuan dan pengawasan Tuhan.

Adapun aspek ibadah yang paling pokok adalah menyangkut masalah, yaitu: 1) Perintah shalat, yaitu melaksanakan shalat fardu lima kali sehari, dan shalat nawafil lainnya, 2) Perintah amar ma'ruf. Dalam pelaksanaannya pada anak-anak adalah anak-anak dibiasakan dalam berhubungan dengan manusia dengan mengerjakan amal-amal shaleh dan menyuruh orang lain melakukan kebaikan, 3) Perintah mencegah yang munkar. Bagi anak prakteknya adalah ditanamkan kepada anak akan rasa benci dan tidak melakukan segala perbuatan yang munkar yaitu segala perbuatan yang bertentangan dengan agama, 4) Perintah melaksanakan kesabaran dalam menghadapi segala ujian, cobaan yang menimpanya. Pada aspek pendidikan akhlak meliputi: Etika pergaulan yang baik yang perlu ditanamkan kepada anak, meliputi: a) Bertutur kata yang lemah lembut dengan siapapun, terutama dengan orang tua, $b$ ) Larangan berlaku sombong atau takabur dengan siapapun juga baik dalam berbicara (tidak memalingkan muka) maupun berjalan, c) Berlaku sederhana dalam hidup dan kehidupannya.

\section{Referensi}

Abdul Latief, Perencanaan Sistem Pengajaran Pendidikan Agama Islam (Bandung, Indonesia: Pustaka Bani Quraisy, 2006)

Abdullah Nashih Ulwan, Tarbiyat Al-Aulad Fi Al-Islam (Beirut: Dar al-Salam, 1971)

${ }^{37}$ Nurwadjah Ahmad E.Q. 
Abi al-Fadli Syihab al-Din al-Sayid Mahmud al-Alusi al-Bagdadi, Rûh Al-Ma'ânî Fî̀ Tafsîr al-Qur'ân al'Aî̀m Wa al-Sab'i al-Maåânî (Beirut: Daral-Kutub Ilmiyah, 1992)

Abi al-Òasan Muhammad, Al-Nuktu Wa al-'Uyûn Tafsîr al-Mâwardî̀ (Beirut: Dâr al-Kutub al'Ilmiah, t.th)

Ahmad Tafsir, Pendidikan Agama Dalam Keluarga (Bandung, Indonesia: PT Remaja Rosdakarya, 2000)

Al-Imam al-Jalil al-Hafiz Abu al-Fidâ Isma'îl Ibnu Kaåîr al-Qursyi al-Dimasqi, Tafsîr Al-Qur'an al'Aì̀m, Terj. Bahrun Abu Bakar (Bandung, Indonesia: Sinar Baru Algensindo, 2006)

Djawad Dahlan, Pendidikan Keimanan Di Ruman Tangga Bagi Anak Usia 0-5 Tahun, Dalam Pendidikan Agama Dalam Keluarga (Bandung, Indonesia: PT Remaja Rosdakarya, 2003)

Hasan Langgulung, Manusia dan pendidikan: suatu analisa psikologi, filsafat dan pendidikan (Jakarta: Al Husna Zikra, 1995)

Maragi, Tafsir Al-Maragi, Terj. Bahrun Abu Bakar (Semarang: Toha Putra, 1992)

Maulana Muhammad Ali, Islamologi (Jakarta: PT Ikhtiar Baru, 1980)

M.Quraish Shihab, Tafsir Al-Misbah,Pesan (Jakarta: Lentera Hati, 2005)

Muhammad Jamâl al-Dîn al-Qâsimî, Tafsîr Al-Qâsimi al-Musammâ Mâhasin al Ta'wîl (Beirut: Dar al-Fikr, t.th)

Nurwadjah Ahmad E.Q, Tafsir Ayat-Ayat Pendidikan (Bandung, Indonesia: Marja, 2007)

Shihab, M. Quraish, and Ihsan Ali-Fauzi, 'Membumikan' Al-Qur'an: fungsi dan peran wahyu dalam kehidupan masyarakat (Bandung: Mizan, 2002)

Suriadi, 'Character Education of Children in the Family', Madaniyah, 9.2, 251-67 $<$ https://journal.stitpemalang.ac.id/index.php/madaniyah/article/view/127>

- 'Hakikat Fitrah Manusia Dalam Islam', 2020, 85-100 <https://doi.org/10.35905/alishlah.v18i1.1278>

- 'Pendidikan Agama Dalam Keluarga', $15.2 \quad$ (2019), 89-105 <https://doi.org/10.32939/tarbawi.v15i1.326>

Wahbah al-Zuhaili, Al-Tafsîr al-Munîr Fî al-'Aqî̀dah Wa al-Earî'Ah Wa al-Manhaj (Damsyik: Dâr al-Fikr, t.th)

Zakiah Daradjat, Ilmu Jiwa Agama (Jakarta: Bulan Bintang, 1970) 